\title{
Correction to: The disvalue of knowledge
}

\section{David Papineau ${ }^{1,2}$}

Published online: 17 October 2019

(c) Springer Nature B.V. 2019

\section{Correction to: Synthese https://doi.org/10.1007/s11229-019-02405-4}

The original article has been corrected.

Publisher's Note Springer Nature remains neutral with regard to jurisdictional claims in published maps and institutional affiliations.

The original article can be found online at https://doi.org/10.1007/s11229-019-02405-4.

$凶$ David Papineau

david.papineau@kcl.ac.uk

1 King's College London, London, UK

2 Graduate Center, City University of New York, New York, USA 